\title{
Aplikasi Konsep Rekreatif pada Perencanaan Desain Budidaya dan Pengolahan Aren di Tuban
}

\author{
Danny Tri Pamungkas ${ }^{1}$, Sigit Hadi Laksono ${ }^{2}$, Nareswarananindya ${ }^{3}$ \\ 1,2,3 Jurusan Arsitektur, Fakultas Teknik Sipil dan Perencanaan, Institut Teknologi Adhi Tama Surabaya \\ Email: ${ }^{1}$ dannypamungkas12@gmail.com
}

\begin{abstract}
Palm tree (Arenga pinnata Merr.) is a multipurpose tree and it has been known that palm tree produces industrial materials. In East Java, palm plant spreads in all of north coast, especially in Tuban. Based on the problem, Palm Cultivated and Processing Center is designed to support government's plans and programs in the develop of the first cultivation and processing palm plant in Indonesia with the theme of Agro-tourism. The design concept is "Recreational" which is something that can provide entertainment that is creative, unique, and different from the others. So that a design will provide pleasant entertainment. The purpose of this article is as a Palm Cultivation and Processing Center in Tuban where there are facilities such as cultivation land along with processing and outdoor tourism facilities such as Flying Fox and Playground.
\end{abstract}

Keywords: Aren, Cultivation, Recreational.

\begin{abstract}
Abstrak. Pohon Aren (Arenga pinnata Merr.) adalah pohon serbaguna yang sejak lama telah dikenal menghasilkan bahan-bahan industri. Tanaman Aren di Jawa Timur tersebar di seluruh pesisir pantai utara khususnya di daerah Tuban. Berdasarkan permasalahan diatas, Pusat Budidaya dan Pengolahan Aren dirancang untuk mendukung program dan rencana pemerintah dalam upaya pengembangan budidaya dan sekaligus pengolahan aren pertama di Indonesia yang bertema agrowisata. Konsep desain adalah "Rekreatif" merupakan sesuatu yang dapat memberikan hiburan yang kreatif, memiliki keunikan, dan berbeda dengan yang lain. Sehingga sebuah rancangan akan memberikan hiburan yang menyenangkan. Tujuan dari artikel ini sebagai Pusat Budidaya dan Pengolahan Aren di Tuban yang mana terdapat fasilitas seperti lahan budidaya beserta pengolahan dan sarana wisata outdoor seperti Flying Fox dan Playground.
\end{abstract}

Kata Kunci: Aren, Budidaya, Rekreatif

\section{Pendahuluan}

Pohon Aren (Arenga Pinnata Merr) adalah pohon serbaguna yang sejak lama telah dikenal menghasilkan bahan-bahan industri. Hampir semua bagian fisik dan produksi tumbuhan ini dapat dimanfaatkan dan memiliki nilai ekonomi. Tanaman Aren di Jawa Timur tersebar di seluruh pesisir pantai utara khususnya di daerah Tuban. Perencanaan Budidaya dan Pengolahan Aren dirancang untuk mendukung program dan rencana pemerintah dalam upaya pengembangan budidaya dan sekaligus pengolahan aren pertama di Indonesia yang bertema agrowisata. Konsep desain adalah "Rekreatif" merupakan sesuatu yang dapat memberikan hiburan yang kreatif, memiliki keunikan, dan berbeda dengan yang lain. Sehingga sebuah rancangan akan memberikan hiburan yang menyenangkan. Tujuan dari Artikel ini sebagai Pusat Budidaya dan Pengolahan Aren di Tuban yang mana terdapat fasilitas seperti lahan budidaya beserta pengolahan dan sarana wisata outdoor seperti Flying Fox dan Playground.

\section{Tinjauan Pustaka}

Dwi Arini (2017), mengartikan rekreatif sebagai suatu kegiatan yang bersifat rekreasi. Rekreasi biasanya dilakukan saat seseorang memiliki waktu luang, Ketika terbebas dari pekerjaan atau Tugas. Definisi rekreatif dalam sebuah perancangan merupakan sesuatu yang dapat memberikan hiburan yang kreatif, memiliki keunikan, dan berbeda dengan yang lain. Sehingga sebuah rancangan akan memberikan hiburan yang menyenangkan.

Menurut Windia et al. (2013) agrowisata adalah kegiatan yang mengkaitkan dan memanfaatkan kegiatan pertanian untuk kegiatan pariwisata dengan tujuan untuk meningkatkan kesejahteraan 
masyarakat setempat. Hal senada juga diungkapkan oleh Muzha (2013) pertanian sebagai objek wisata memiliki tujuan untuk memperluas pengetahuan, pengalaman rekreasi, dan hubungan usaha di bidang pertanian yang bertempat di lingkungan setempat serta melibatkan masyarakat setempat. Melalui pengembangan agrowisata yang menonjolkan budaya lokal dalam memanfaatkan lahan, pendapatan petani dapat meningkat bersamaan dengan upaya melestarikan sumberdaya lahan, serta memelihara budaya maupun teknologi lokal (indigenous knowledge) yang umumya telah sesuai dengan kondisi lingkungan alaminya.

Setiawan (2009) mengemukakan bahwa, agrowisata adalah pengembangan dari budidaya agro dan pariwisata. Wisata yang dimaksud mengusung atraksi berupa pertanian, perkebunan atau perhutanan. Sehingga dapat diartikan sebagai pengelohan lahan perkebunan yang di jadikan suatu objek wisata, lengkap dengan atraksi wisatanya yang menarik bagi wisatawan. Dalam pengembangan agrowisata, perlu menyadari adanya simbiosis mutualisme antara pelestarian sumberdaya alam dan lingkungan hidup, jika melakukan pendekatan yang berwawasan lingkungan / eco-tourism. Keterbinaan sumberdaya alam dan kelestarian lingkungan hidup, merupakan hal utama yang dibutuhkan. Hasil dari usaha pengembangan budidaya agro dan pariwisata, dapat diteruskan untuk melestarikan sumberdaya alam dan lingkungan hidup. Hubungan timbal balik ini akan berlangsung secara harmonis dalam jangka panjang.

Menurut Bernhard (2007) dalam jurnal berjudul Teknik Budidaya dan Rehabilitasi Tanaman Aren, Budidaya aren yakni suatu bentuk usaha tani yang dapat meningkatkan produktivitas tanaman dan lahan yang dapat meningkatkan pendapatan petani. Beberapa faktor harus diperhatikan adalah lahan dan iklim yang sesuai, benih dan bibit unggul serta pemeliharaan yang baik.

Menurut Lubis and Sihombing, (2014) dalam jurnal berjudul Analisis Nilai Tambah Usaha Pengolahan Gula Aren Di Desa Suka Maju Kecamatan Sibolangit Kabupaten Deli Serdang, Pengolahan nira menjadi gula aren merupakan pengolahan yang dilakukan untuk memperoleh nilai tambah. Perhitungan nilai tambah tersebut bertujuan untuk mengukur besarnya tambahan nilai yang dapat diperoleh petani dari pengolahan satu liter nira menjadi gula aren.

\section{Metode Penelitian}

Jenis penelitian yang digunakan adalah penelitian deskriptif kualitatif, penelitian ini berkaitan dengan pengumpulan data untuk memberikan gambaran tentang suatu gejala, umumnya dilakukan dengan metode survey, wawancara, pengamatan, studi kasus, studi korelasi, dan sebagainya. Adapun teknik pengumpulan data yang dipakai untuk mendukung dalam penelitian ini adalah interview, literatur, dan dokumentasi.

\section{Pembahasan}

Pembahasan ini menyajikan proses penyusunan konsep desain, mulai dari pengumpulan objek studi banding, penyusunan program ruang, analisa site, program rancangan, hingga hasil berupa konsep rancangan dari fasilitas untuk budidaya dan pengolahan aren.

\subsection{Studi Banding}

Hasil Observasi studi banding literatur menghasilkan data yang dapat digunakan untuk merancangan dan membuat program ruang serta desain pada Pusat Budidaya dan Pengolahan Aren pada Lahan Berkontur dengan Tema Rekreatif. Studi banding literatur menggunakan Bali Pulina, Kusuma Agrowisata, Agrowisata Taman Suruh, dan Bagus Agro Pelaga. 

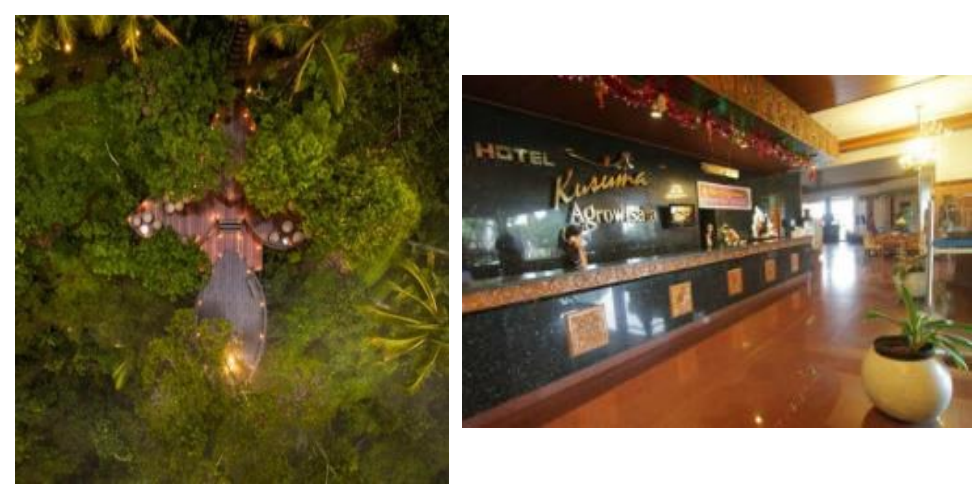

Gambar 1. (kiri) Bali Pulina; dan (kanan) Kusuma Agrowisata
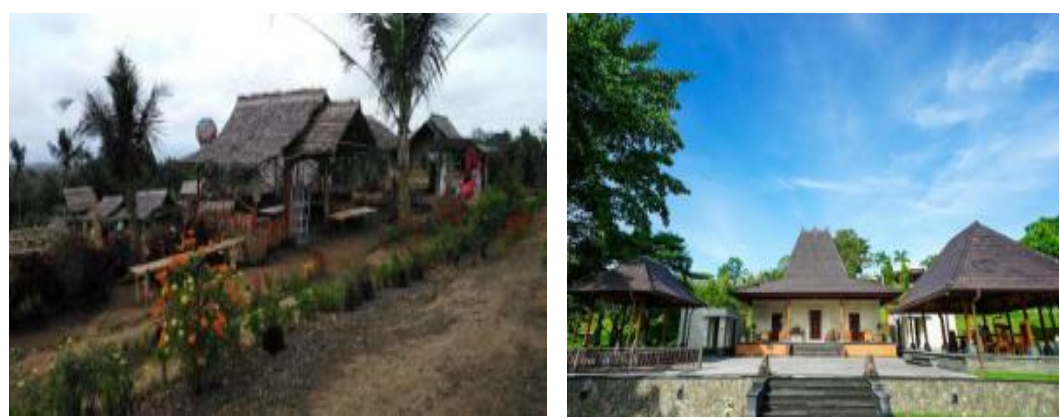

Gambar 2. (kiri) Agrowisata Taman Suruh; dan (kanan) Bagus Agro Pelaga

Desain yang saya gunakan yaitu terinspirai dari konsep studi literatur Kusuma Agrowisata karena pada studi ini terdapat unsur - unsur yang sesuai dengan konsep yang saya gunakan seperti contoh terdapat sarana Rekreatif seperti kolam renang, Arena Outbond, dan wahana Edukatif lainnya.

\subsection{Program Ruang}

Yang dilakukan pada program ruang yaitu melakukan proses identifikasi dan mendefinisikan kebutuhan-kebutuhan perancangan tersebut, serta untuk kebutuhan pengguna. Pada aspek-aspek yang sudah dijelaskan yaitu berdasarkan: organisasi ruang keseluruhan dan besaran ruang keseluruhan.

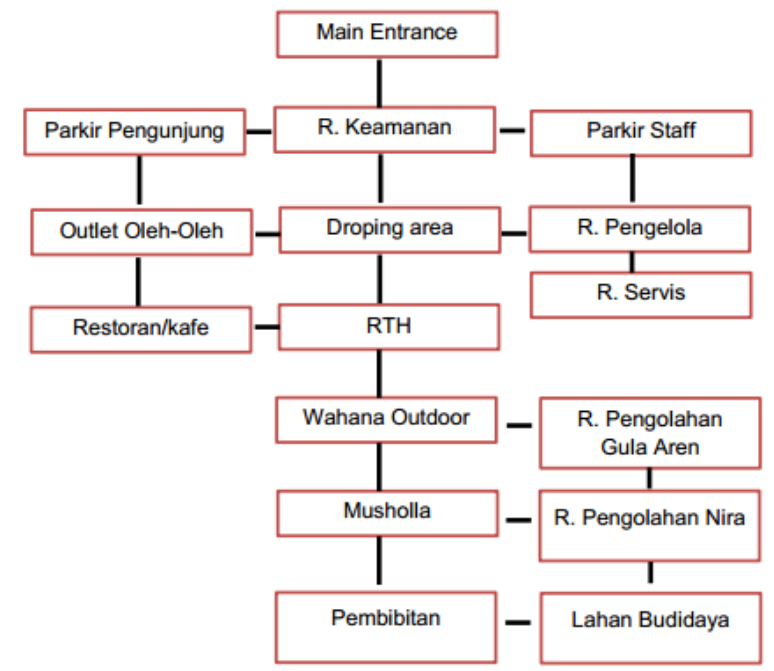

Gambar 3. Organisasi Ruang Keseluruhan Sumber: Data Pribadi 


\begin{tabular}{|l|l|}
\hline BESARAN & JENIS FASILITAS \\
\hline $540.15 \mathrm{~m}^{2}$ & Fasilitas Penerima \\
\hline $600.6 \mathrm{~m}^{2}$ & Fasilitas Utama \\
\hline $360.4 \mathrm{~m}^{2}$ & Fasilitas Pengelola \\
\hline $340.6 \mathrm{~m}^{2}$ & Fasilitas Penunjang \\
\hline \hline $326.3 \mathrm{~m}^{2}$ & Fasilitas Servis \\
\hline $\begin{array}{l}24.7 \mathrm{~m}^{2} \\
\text { Total Luas } \\
\text { Bangunan }\end{array}$ & Fasilitas Keamanan \\
\hline KDB $60 \%$ & $2.192,75$ \\
\hline Total Luas Lahan & $\mathbf{3 . 5 0 8 , 4}$ \\
\hline
\end{tabular}

Gambar 4. Besaran Ruang Keseluruhan

Sumber: Data Pribadi

\subsection{Analisa Site}

Lokasi lahan yang strategis dikarenakan lahan atau site rancangan berada di wilayah perbukitan dan dekat dengan tempat wisata, sehingga mendukung segala aspek perencanaan yang meliputi judul yang akan di kembangkan.

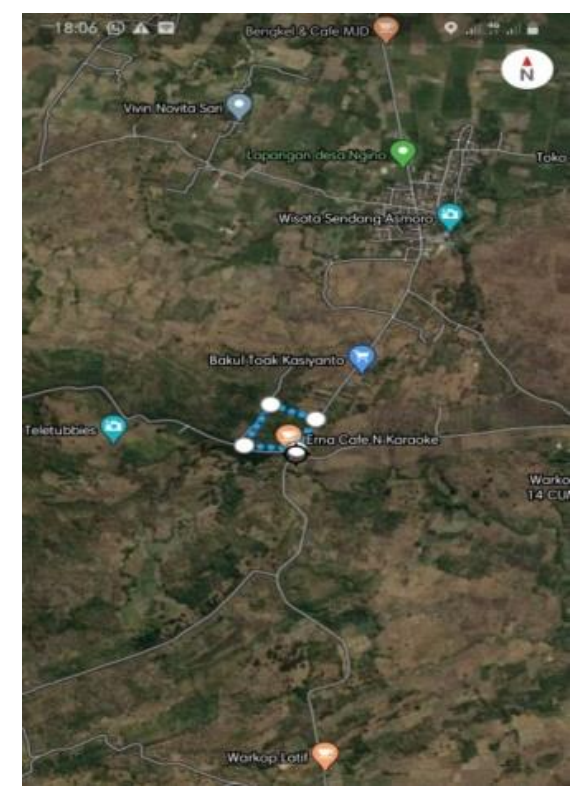

Gambar 5. Lokasi Site

Sesuai data dari RTRW (Rencana Tata Ruang Wilayah) Kabupaten Tuban no. 9 Tahun 2012 2032, Lokasi site diperuntukan sebagai hutan produksi atau budidaya. Site rancangan berada di perbukitan dan masuk dalam kawasan wisata dan kebun aren sehingga efektif untuk membangun sebuah Pusat Budidaya dan Pengolahan Aren. Akses mudah dicapai karena lokasi berdekatan dengan tempat Wisata Bukit Teletubies dan Wisata Sendang Asmoro.

\subsection{Hasil Rancangan}

Hasil rancangan terdiri dari rancangan tatanan lahan, rancangan bentuk, dan rancangan ruang, yang dapat dilihat pada gambar-gambar berikut: 


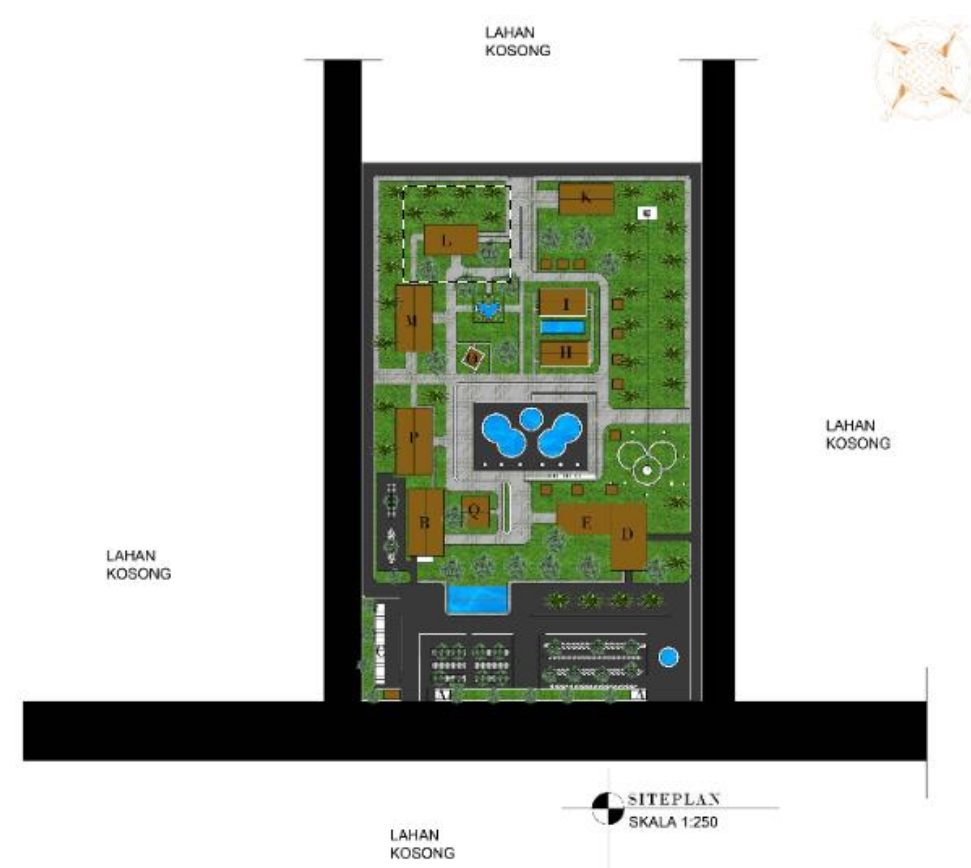

Gambar 6. Program Rancangan Tatanan Lahan

Rancangan Tatanan Lahan menggunakan konsep Joyfull yang artinya menyenangkan dan diharapkan dapat membuat suasana budidaya menjadi lebih enjoy dan menyenangkan (lihat Gambar 5). Sehingga dapat dinyatakan bahwa perancangan menggunakan Mikro Konsep Tatanan Lahan "Joyfull". Konsep yang menyenangkan dan diharapkan dapat membuat suasana ruang terbuka menjadi lebih enjoy dan menyenangkan dalam proses budidaya.

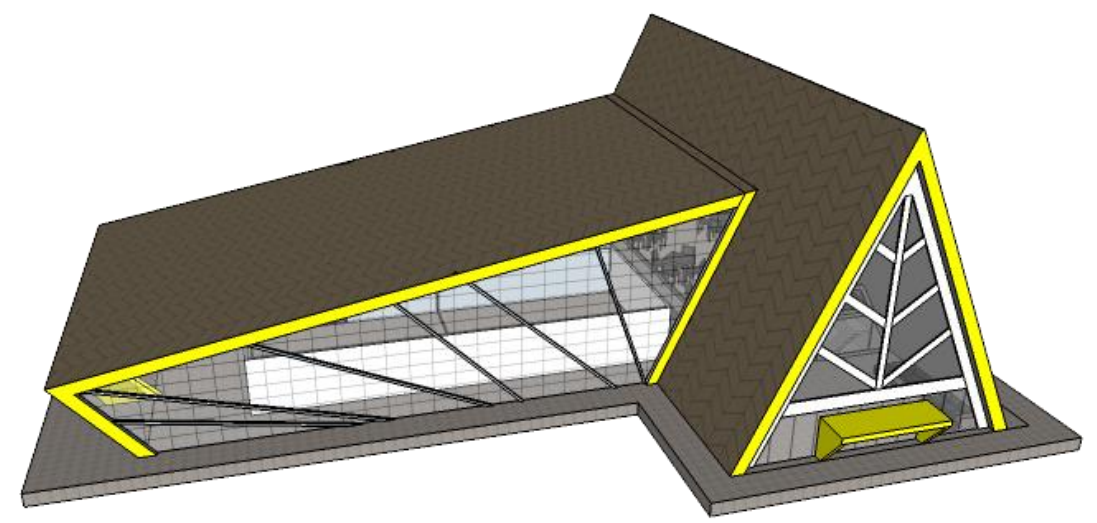

Gambar 7. Program Rancangan Bentuk

Rancangan Bentuk menggunakan konsep Analogi yang artinya suatu desain yang mencapai persamaan dan kesamaan terhadap benda atau objek, bentuk analogi saya menggunakan analogi batang daun aren yang menjadi ornamen di sekitar dinding bangunan dan atap (lihat Gambar 6). Perancagan bentuk tersebut menggunakan Mikro Konsep Bentuk "Analogi”. Bentuk yang dihasilkan merupakan suatu usaha untuk mencapai persamaan dan kesamaan terhadap benda-benda, ataupun antara perwujudan arsitektur dengan berbagai macam hal. Bentuk analogi ini diharapkan dapat menjadikan ikon dari Agrowisata Aren. 

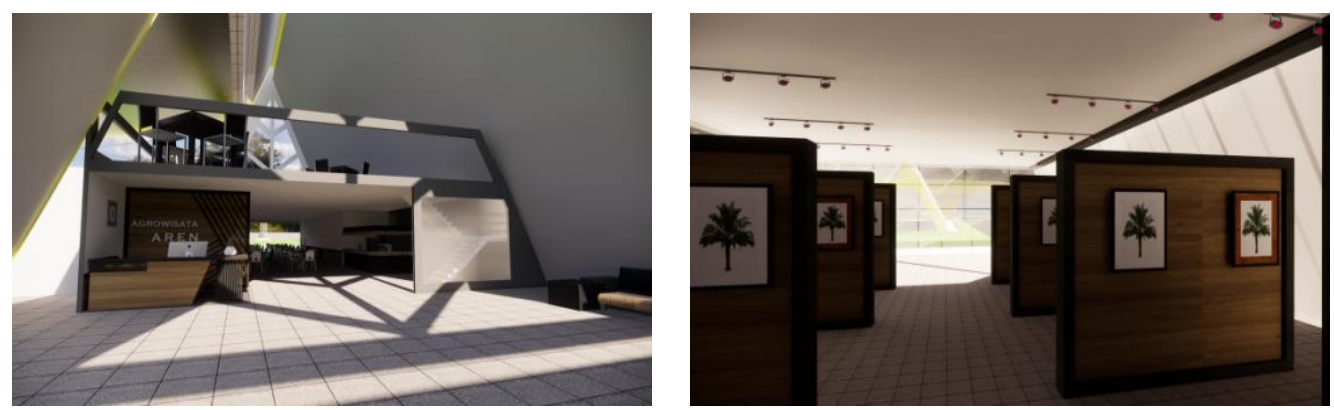

Gambar 8. Program Rancangan Ruang

Rancangan Ruang menggunakan konsep Edukatif yang artinya segala sesuatu bersifat mendidik, memberikan pembelajaran dan amanat, diharapkan dengan konsep ini dapat menjadikan suasana ruang yang baik untuk proses mendidik. Dalam hal ini dapat dijustifikasi bahwa perancangan menggunakan Mikro Konsep Ruang "Edukatif".

\section{Kesimpulan}

Aplikasi Konsep Rekreatif pada Perencanaan Desain Budidaya dan Pengolahan Aren di Tuban ini adalah sebagai bentuk upaya pemberdayaan pohon aren dengan membudidayakan serta pengolahan dari hasil pohon Aren dan sekaligus tempat rekreasi. bertujuan untuk meningkatkan populasi pohon aren di Pulau Jawa khususnya Tuban Jawa. Dikarenakan budidaya dan pengolahan aren sendiri masih belum banyak di daerah Tuban Jawa Timur.

Konsep desain perencanaan Budidaya dan Pengolahan Aren di Tuban adalah "Rekreatif" merupakan sesuatu yang dapat memberikan hiburan yang kreatif, memiliki keunikan, dan berbeda dengan yang lain. Sehingga sebuah rancangan akan memberikan hiburan yang menyenangkan. Tujuan dari Artikel ini sebagai Pusat Budidaya dan Pengolahan Aren di Tuban yang mana terdapat fasilitas yang menarik dan menyenangkan beserta sarana dan prasarana seperti lahan budidaya, lahan pembibitan, tempat pengolahan, keamanan dan tempat wisata outdoor seperti Flying Fox dan Playground.

\section{Referensi}

Bernhard, Maliangkay Ronny. 2007. "Teknik Budidaya dan Rehabilitasi Tanaman Aren,” no. 33: 11.

Dwi Arini, N. M. (Alumni Prodi Teknik Arsitektur Universitas Ngurah Rai), N. P. N. (Prodi Teknik Arsitektur Fakultas Teknik Universitas Ngurah Rai) Nityasa, and K. W. (Prodi Teknik Arsitektur Fakultas Teknik Universitas Ngurah Rai) Yudiata. 2017. "Resor Agrowisata Di Pelaga." Jurnal Teknik Gradien 9 (1): 37-63.

Kushardianti Muzha, Vianda, Heru Ribawanto, and Minto Hadi. 2012. "PENGEMBANGAN AGROWISATA DENGAN PENDEKATAN COMMUNITY BASED TOURISM (Studi Pada Dinas Pariwisata Kota Batu Dan Kusuma Agrowisata Batu)." Jurnal Administrasi Publik (JAP), 7.

Lubis, Wenny Wulandari, and Luhut Sihombing. n.d. "ANALISIS NILAI TAMBAH USAHA PENGOLAHAN GULA AREN DI DESA SUKA MAJU KECAMATAN SIBOLANGIT KABUPATEN DELI SERDANG," 13.

Setiawan, Ahmad Taufiq. 2009. "Perancangan Agrowisata Di Argomulyo Kota Salatiga Dengan Pendekatan Arsitektur Ecotourism," 23.

Windia, Wayan, Made Wirartha, Ketut Suamba, and Made Sarjana. 2013. "MODEL PENGEMBANGAN AGROWISATA DI BALI," 14. 